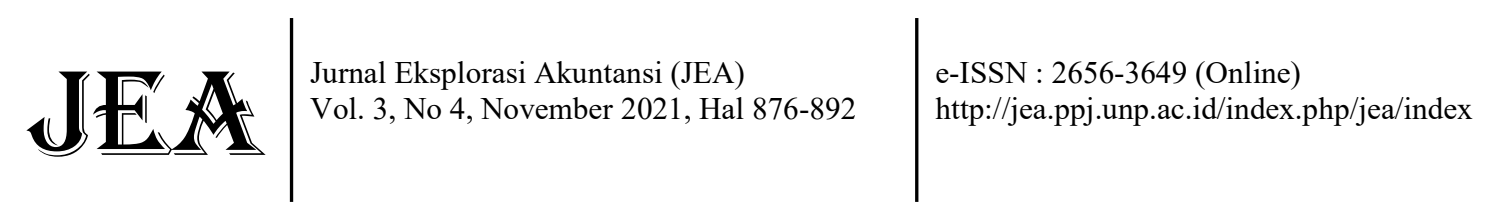

\title{
Pengaruh Islamic Corporate Social Responsibility (ICSR) dan Sharia Governance Terhadap Kinerja Bank Umum Syariah
}

\author{
Ashry Salamayrika Rahmawaty ${ }^{1 *}$, Nayang Helmayunita ${ }^{2}$ \\ ${ }^{1,2}$ Fakultas Ekonomi, Universitas Negeri Padang \\ *Korespondensi: ashry.sr@gmail.com
}

\begin{abstract}
This study aims to examine the effect of Islamic Corporate Social Responsibility (ICSR) and Sharia Governance on the performance of Islamic commercial banks. This research is quantitative through time series and cross section data. The population in this study are Islamic commercial banks registered with the Financial Services Authority in 2015-2019. By using purposive sampling method, there are 8 Islamic commercial banks as research samples. Performance variables were measured using Return On Assets (ROA), Return On Equity (ROE), Net Interest Margin (NIM), and Capital Adequacy Ratio (CAR). The ICSR variable is measured using the ISR index and the Sharia Governance variable is measured using the number of Sharia Supervisory Board meetings. The analytical method used is multiple regression analysis. The results of this study indicate that ICSR has no significant effect on ROA, Sharia Governance has a positive and significant effect on ROA, ICSR has no significant effect on ROE, Sharia Governance has a positive and significant effect on ROE, ICSR has a positive and significant effect on NIM, Sharia Governance has a negative and significant effect on NIM, ICSR has no significant effect on CAR, and Sharia Governance has a significant and negative effect on CAR.
\end{abstract}

Keywords : Islamic Corporate Social Responsibility; Sharia Governance; Return On Asset; Return On Equity; Net Interest Margin; Capital Adequacy Ratio.

How to cite (APA 6 $^{\text {th }}$ style)

Rahmawaty, A. S. dan Helmayunita, N. (2021). Pengaruh Islamic Corporate Social Responsibility (ICSR) dan Sharia Governance Terhadap Kinerja Bank Umum Syariah. Jurnal Eksplorasi Akuntansi (JEA), 3 (4), 876-892.

\section{PENDAHULUAN}

Bank syariah adalah adalah lembaga keuangan yang setiap aktivitas yang dilakukan harus berdasarkan prinsip syariah. Menurut Otoritas Jasa Keuangan (OJK), bank syariah yang pertama kali didirikan yaitu Bank Muamalat Indonesia yang dibangun pada tanggal 1 November 1991 yang merupakan hasil kerja Tim Perbankan MUI dalam mendirikan Bank Islam di Indonesia. Bank Muamalat Indonesia resmi beroperasi dengan modal awal sebesar Rp106.126.382.000,- dan itulah yang membuatnya terus mengalami perkembangan pada perbankan syariah. 
Tabel 1

Perbandingan Jumlah Bank dan Total Aset pada Bank Syariah dan Bank Konvensional Tahun 2015-2019

\begin{tabular}{ccccccc}
\hline \multicolumn{2}{c}{ TAHUN } & $\mathbf{2 0 1 5}$ & $\mathbf{2 0 1 6}$ & $\mathbf{2 0 1 7}$ & $\mathbf{2 0 1 8}$ & $\mathbf{2 0 1 9}$ \\
\hline Bank Syariah & $\begin{array}{c}\text { Jumlah Bank } \\
\text { Total Aset } \\
(\mathrm{M})\end{array}$ & 12 & 12 & 13 & 13 & 14 \\
& 213.423 & 254.184 & 288.027 & 316.691 & 350.364 \\
$\begin{array}{c}\text { Bumk } \\
\text { Kanvensional Bank }\end{array}$ & 118 & 116 & 115 & 115 & 110 \\
& $\begin{array}{c}\text { Total Aset } \\
(\mathrm{M})\end{array}$ & 6.095 .908 & 6.729 .799 & 7.387 .634 & 7.913 .491 & 8.562 .974 \\
\hline
\end{tabular}

Sumber : www.ojk.go.id

Dari data statistika Otoritas Jasa Keuangan menunjukkan pada tahun 2015 Bank Umum Syariah berjumlah 12 bank dengan total aset sebesar 213.423 M. Berikutnya Bank Umum Syariah mengalami peningkatan pada tahun 2019 yaitu sebanyak 14 bank dengan total aset 350.364 M. Sedangkan pada Bank Konvensional, pada tahun 2015 terdapat 118 bank dengan total aset $6.095 .908 \mathrm{M}$. Kemudian terjadi penurunan pada tahun 2019 yaitu menjadi 110 bank dengan total aset $8.562 .974 \mathrm{M}$. Pertumbuhan bank syariah yang semakin meningkat akan menyebabkan tejadinya persaingan ketat antar bank. Hal ini membuat bank syariah dituntut untuk meningkatkan atau mempertahankan kinerjanya.

Kinerja adalah sesuatu pencapaian yang dihasilkan oleh seorang/sekelompok orang dalam melakukan tugasnya. Menurur Rudianto (2003), kinerja merupakan cerminan pencapaian dalam penerapan aktivitas ataupun program supaya bisa mewujudkan visi, misi, tujuan serta target organisasi. Kinerja perusahaan ialah pencapaian perusahaan yang dilaksanakan oleh seorang maupun sekelompok orang yang berwenang dan bertanggung jawab menjalankan tugasnya dalam mencapai tujuan perusahaan supaya sesuai dengan aturan yang berlaku (Rivai dan Basri, 2004). Kinerja perusahaan diperlukan untuk mengetahui bagaimana aktivitas perusahaan setiap tahunnya baik dalam bentuk laporan keuangan maupun non-keuangan agar dapat mencapai tujuan perusahaan. Hal ini perlu dilakukan terutama dalam dunia perbankan salah satunya yaitu bank syariah.

Di bank syariah memakai sistem bagi hasil dan hal ini berbeda dengan sistem bunga di bank konvensional. Di bank syariah tidak memakai sistem bunga karena merupakan bagian dari riba. Keuntungan dari bunga bersifat tetap tanpa melihat hasil usaha, dan keuntungan dari bagi hasil akan mengalami perubahan sesuai hasil usaha dari pihak penerima dana (Ismail, 2011). Sehingga keberadaan bank syariah sangat penting untuk kebutuhan masyarakat muslim terutama untuk menghindari riba karena riba termasuk kategori yang dilarang dalam Islam. Hal ini terdapat dalam Al-Qur'an dalam QS. Ali Imran ayat 130 yang artinya:

"Hai orang-orang yang beriman, janganlah kamu memakan riba dengan berlipat ganda dan bertakwalah kamu kepada Allah supaya kamu mendapat keberuntungan."

Untuk menentukan keberhasilan bank syariah dapat dilihat bagaimana kinerja bank syariah tiap periode, baik dari kinerja keuangan maupun non-keuangan. Untuk mendapatkan kepercayaan dari nasabah, maka diperlukan kinerja yang baik (Sukarno, Kartika, dan Syaichu, 2006). Kinerja bank syariah dapat dilihat dengan menggunakan indikator yang terdiri dari ROA, NPF dan market share. ROA bank syariah pada November 2020 adalah sebesar 1,35\%, sedangkan ROA bank konvensional pada November 2020 yaitu sebesar 1,64\%. Hal ini menunjukkan bahwa ROA bank konvensional masih unggul daripada bank syariah. NPF 
bank syariah pada November 2019 yaitu sebesar 3,22\% apabila dibandingkan dengan NPF bank konvensional yaitu sebesar 2\%. Hal ini menunjukkan bahwa rasio kredit bermasalah pada bank syariah lebih tinggi daripada bank konvensional.

Dalam CNN Indonesia, market share bank syariah di Indonesia sampai Oktober 2020 hanya sebesar 6,33\%. Ini menunjukkan bahwa angka tersebut tidak bergerak signifikan jika dibandingkan dengan market share tahun 2017, yaitu sebesar 5\%. Padahal di Indonesia, mayoritas penduduknya adalah muslim, seharusnya ini bisa menjadi peluang besar untuk bank syariah agar dapat memperluas pasarnya. Tetapi hal ini tidak bisa menjamin bahwa bank syariah dapat berkembang dengan cepat jika diingat lagi bahwa bank syariah sudah berdiri selama 29 tahun. Hal ini bisa dikatakan bahwa kinerja bank syariah masih belum baik. Oleh karena itu, perlu diuji untuk mengetahui apa saja faktor-faktor yang mempengaruhi kinerja bank umum syariah.

Salah satu faktor yang dapat mempengaruhi kinerja bank umum syariah adalah Islamic Corporate Social Responsibility atau disebut dengan ICSR. Islamic Corporate Social Responsibility ialah CSR islami yang diperoleh dari CSR konvensional (Sidik dan Reskino, 2016). Menurut Khursid et al., (2014), ICSR adalah tanggung jawab sosial yang memiliki nilai-nilai Islami dan terdapat di dalam Al-Qur'an dan hadist. Ajaran Islam dan CSR yang terdapat dalam UN Global Compact tidak memiliki perbedaan, tapi dengan mempunyai kodifikasi etik dan mekanisme yang jelas dapat membuat Islam semakin maju (William dan Zinkin, 2010). Sehingga dapat disimpulkan bahwa ICSR ini begitu penting untuk bank syariah agar dapat mengetahui apakah setiap aktivitasnya sesuai dengan prinsip-prinsip syariah yang dapat dilihat dalam bentuk pengungkapan yang terdapat pada laporan tahunannya. Pada ICSR ini dibuat dalam bentuk pengungkapan-pengungkapan yang digunakan untuk memberikan informasi kepada stakeholder agar dapat mengetahui kegiatan tanggung jawab sosial yang dilakukan oleh bank syariah. Dalam signalling theory menjelaskan semakin baik informasi yang diberikan bank syariah maka semakin baik pula kinerjanya. Dengan adanya ICSR ini diharapkan bank syariah dapat memberikan pengungkapan yang lebih informatif untuk menghasilkan kinerja yang lebih baik. Kepercayaan investor juga akan meningkat apabila dengan adanya kegiatan tersebut, maka perusahaan memiliki potensi untuk menghasilkan laba yang lebih besar dibandingkan dengan perusahaan yang tidak melakukan kegiatan tanggung jawab sosial (Arshad, 2012).

Faktor berikutnya yang mempengaruhi kinerja bank umum syariah adalah Sharia Governance. Sharia Governance dalam IFSB adalah kumpulan peraturan untuk lembaga keuangan syariah untuk mengetahui adanya pandangan independen mengenai kepatuhan syariah dalam melakukan proses penerbitan, penyebaran informasi, dan review internal. Di bank syariah, Sharia Governance yaitu penggabungan dari konsep Good Corporate Governance dan Sharia Compliance (Wardayati, 2011). Prinsip syariah dalam konteks Indonesia yaitu bahwa Dewan Syariah Nasional (DSN) yang dibentuk oleh Majelis Ulama Indonesia (MUI) mengeluarkan prinsip hukum syariah dimana kegiatan yang dilakukan bank syariah harus berdasarkan hukum Islam berdasarkan fatwa yang terdapat pada UU No 21 Tahun 2008 tentang Perbankan Syariah Pasal 1 ayat 12. Pada bank syariah, penerapan GCG adalah penerapan yang dibutuhkan oleh bank syariah karena merupakan tanggung jawabnya pada masyarakat, supaya nilai pemegang saham meningkat maka pengelolaan di bank syariah harus dilakukan dengan baik, profesional dan hati-hati. Berikutnya dari bagian Sharia Governance yaitu Shariah compliance dimana bank syariah harus mematuhi prinsip syariah karena merupakan kewajibannya. Implementasi GCG dalam perbankan syariah, supaya dapat memastikan bahwa bank syariah memenuhi prinsip syariah, maka diwajibkan untuk melakukan penerapan shariah compliance.

Menurut Rama dan Novela (2015), keberadaan Dewan Pengawas Syariah merupakan elemen penting dari sharia governance dimana dalam proses supervisi, monitoring, audit dan 
pemberian opini terhadap kepatuhan syariah merupakan peranan penting dari struktur organisasi pada lembaga keuangan syariah. Untuk Sharia Governance dilihat dari jumlah Rapat Dewan Pengawas Syariah (DPS). Hal ini terdapat pada peraturan peraturan BI Nomor 11/33/PBI tahun 2009 di pasal 49 yang menjelaskan bahwa GCG yang dilakukan baik di Bank Umum Syariah maupun Unit Usaha Syariah, rapat DPS wajib dilakukan setidaknya sekali dalam sebulan, dan keputusan diambil secara musyawarah mufakat. Dari peraturan tersebut dapat menjelaskan bahwa jika sering melakukan rapat DPS, maka kinerja perusahaan akan semakin meningkat karena operasional perusahaan tetap berjalan berdasarkan prinsip syariah (Fauzi, 2016). Hal ini menarik untuk diteliti bagaimana Sharia Governance dalam hal rapat DPS menjalankan tugasnya pada bank syariah.

Pada penelitian ini, grand theory yang digunakan adalah signalling theory dan sharia enterprise theory (SET). Untuk signnalling theory digunakan sebagai basis utama untuk menjelaskan hubungan ICSR dan sharia governance terhadap kinerja. Pada signalling theory, menurut Drevel et.al (2007) dalam Sidik dan Reskino (2016) menyatakan bahwa semakin informatif pengungkapan yang sudah dilakukan perusahaan, maka perusahaan akan mendapatkan nilai yang baik. Sebaliknya, jika perusahaan gagal memberikan pengungkapan akan dinilai sebagai perusahaan yang sama rata dengan perusahaan lain. (Hakkanson, 1983). Hal ini akan dilihat dari ICSR yang dibuat dalam bentuk pengungkapn-pengungkapan dan sharia governance dilihat dari berapa banyak rapat Dewan Pengawas Syariah setiap tahunnya.

Berikutnya sharia enterprise theory digunakan sebagai basis yang menjelaskan variabel ICSR. Dalam SET (Sharia Enterprise Theory) memandang pengungkapan harus dilakukan secara akuntabel dan transparan untuk setiap kegiatan operasi perusahaan agar sesuai dengan prinsip-prinsip syariah untuk mencakup stakeholder secara luas, yakni kepada Tuhan, manusia, dan alam. Apabila keinginan stakeholder yang ingin dipenuhi mengalami kegagalan, akan berakibat hilangnya dukungan dan akses perusahaan terhadap sumber daya yang dibutuhkan (Triwuyono, 2007). Hal ini dapat diketahui bahwa bank syariah harus memberikan pengungkapan yang informatif agar dapat meningkatkan kinerjanya dan dinilai baik oleh masyarakat.

Penelitian mengenai hubungan Islamic Corporate Social Responsibility terhadap kinerja sudah dilakukan sebelumnya oleh Arifin dan Wardani (2016) yang memakai dua proksi yaitu ROE dan ROA yang digunakan untuk mengukur kinerja. Hasil penelitiannya menunjukkan bahwa ICSR memiliki pengaruh yang signifikan terhadap kinerja perusahaan dengan menggunakan ROE, tapi tidak berpengaruh terhadap ROA. Sidik dan Reskino (2016) dalam penelitiannya menunjukkan bahwa ICSR hanya berhubungan positif namun tidak mempunyai pengaruh yang signifikan pada kinerja perusahaan (ROE). Indrayani dan Risna (2018) dalam penelitiannya juga menunjukkan bahwa ICSR tidak memilki pengaruh yang signifikan terhadap kinerja dengan menggunakan ROA. Pada penelitian Marsuni (2019) menunjukkan ICSR berpengaruh dan tidak signifkan terhadap ROA dan ROE.

Selanjutnya penelitian mengenai hubungan Sharia Governance terhadap kinerja sudah dilakukan Sunarwan (2016), hasil penelitiannya menunjukkan bahwa Corporate Governance yang diukur dengan rapat DPS mempunyai pengaruh yang signifikan terhadap kinerja pada bank syariah yang diukur dengan ROA. Penelitian Kartika (2014) menunjukkan bahwa tidak ada pengaruh antara Dewan Pengawas Syariah dengan kinerja perbankan syariah yang diukur dengan NPM. Penelitian Eksandy (2018) menunjukkan bahwa Dewan Pengawas Syariah tidak memiliki pengaruh terhadap kinerja perbankan syariah yang diukur dengan ROA. Indrayani dan Risna (2018) menunjukkan hasil penelitiannya bahwa Sharia Governance tidak memiliki pengaruh terhadap kinerja yang diukur dengan ROA.

Perbedaan penelitian ini dengan sebelumnya yaitu pertama, objek yang digunakan adalah Bank Umum Syariah yang merupakan lembaga keuangan islami sehingga untuk penelitian ini menggunakan variabel independen yaitu Islamic Corporate Social 
Responsibility dan Sharia Governance (gabungan dari GCG dan sharia compliance). Kedua, pada penelitian sebelumnya memiliki hasil yang berbeda-beda sehingga peneliti ingin meneliti untuk mendapatkan hasil yang lebih baik. Ketiga, ada pertentangan dengan teori pada hasil penelitian sebelumnya. Keempat, penelitian yang ingin dilakukan peneliti menggunakan periode 5 tahun yaitu dari tahun 2015-2019 dengan teknik purposive sampling pada seluruh Bank Umum Syariah yang terdaftar di OJK. Kelima, untuk menguji ICSR peneliti meneliti kembali menggunakan indeks ISR dan sharia governance menggunakan pengukuran jumlah rapat Dewan Pengawas Syariah. Pada kinerja dalam penelitian ini menggunakan peraturan OJK Nomor 8/POJK.03/2014, pada penelitian sebelumnya menggunakan rasio profitabilitas yaitu ROA dan ROE sebagai pengukuran kinerja, maka untuk penelitian ini akan ditambahkan lagi dari rasio profitabilitas yaitu NIM (Net Interest Margin) dan rasio kecukupan modal yaitu CAR (Capital Adequacy Ratio).

ROA untuk menggambarkan kemampuan perusahaan dalam menghasilkan laba dari penggunaan aset. Semakin tinggi ROA, maka kemampuan perusahaan semakin baik dalam menghasilkan laba dari penggunaan aset. ROE menggambarkan kemampuan perusahaan dalam menghasilkan laba setelah pajak dari modal sendiri yang dimiliki oleh perusahaan. Semakin tinggi ROE, maka kepercayaan investor semakin meningkat dan ini akan membuat investor bersemangat untuk memberikan investasinya. Pada rasio NIM menggambarkan kemampuan perusahaan dalam menghasilkan pendapatan bunga bersih dengan aktiva produktif. Semakin tinggi nilai NIM, maka kemampuan perusahaan semakin baik karena mampu menghasilkan pendapatan bunga dari aktiva produktif. Berikutnya CAR yang merupakan rasio kecukupan modal, menggambarkan kemampuan perusahaan dalam menyediakan dana untuk mengatasi terjadinya risiko kerugian. Semakin tinggi nilai CAR, maka kemampuan perusahaan dalam menghadapi risiko kerugian akan semakin baik.

Penelitian ini bertujuan menguji pengaruh Islamic Corporate Social Responsibility (ICSR) dan Sharia Governance terhadap bank umum syariah. Hasil penelitian ini diharapkan bisa memberikan manfaat untuk perkembangan literatur ekonomi Islam, memberikan kontribusi untuk peneliti selanjutnya untuk memperluas pengetahuannya, serta dapat membantu pihak manajemen perusahaan dalam pengambilan keputusan untuk menerapkan Islamic Corporate Social Responsibility (ICSR) dan Sharia Governance agar dapat meningkatkan kinerja bank umum syariah.

\section{REVIU LITERATUR DAN HIPOTESIS Signalling Theory}

Signalling Theory digunakan agar dapat mengetahui tujuan pengungkapan CSR untuk perusahaan. Sinyal (sign) ialah pesan yang disampaikan yang berupa peringatan, simbol, maupun tulisan yang bertujuan untuk menyampaikan informasi secara terbuka (Scholastic Dictionary, 2011). Tujuan dari informasi melalui pengungkapan adalah untuk mendapatkan penilaian dari masyarakat supaya dapat menunjukkan bahwa perusahaan memiliki nilai yang lebih baik daripada perusahaan-perusahaan lain (Sidik dan Reskino, 2016).

Pada signalling theory, menurut Drevel et.al (2007) dalam Sidik dan Reskino (2016) menyatakan bahwa semakin informatif pengungkapan yang sudah dilakukan perusahaan, maka perusahaan akan mendapatkan nilai yang baik. Sebaliknya, jika perusahaan gagal memberikan pengungkapan akan dinilai sebagai perusahaan yang sama rata dengan perusahaan lain. (Hakkanson, 1983).

Jadi, signalling theory ini digunakan sebagai basis utama peneliti untuk menjelaskan hubungan Islamic Corporate Social Responsibility dan sharia governance terhadap kinerja. Dalam ICSR akan memberikan informasi melalui pengungkapan-pengungkapan. Semakin informatif pengungkapan yang dibuat oleh bank syariah maka akan semakin baik pula kinerjanya begitupun sebaliknya. Begitu juga dengan sharia governance yang merupakan 
gabungan dari Good Corporate Governance dan Sharia Governance. Hal ini dilihat dari berapa kali rapat Dewan Pengawas Syariah dilakukan setiap tahunnya karena dalam peraturan BI Nomor 11/33/PBI tahun 2009 menjelaskan bahwa GCG yang dilakukan baik di Bank Umum Syariah maupun Unit Usaha Syariah, rapat DPS wajib dilakukan setidaknya sekali dalam sebulan, dan keputusan diambil secara musyawarah mufakat. Hal ini dilakukan agar bank syariah dapat meningkatkan kinerjanya karena perusahaan tetap beroperasional sesuai dengan prinsip-prinsip syariah.

\section{Sharia Enterprise Theory (SET)}

SET dipakai agar dapat mengetahui CSR untuk stakeholder pada perspektif Islam (Sidik dan Reskino, 2016). SET menunjukkan stakeholder bukan hanya manusia maupun alam saja, tetapi Tuhan juga karena segala ativitas dunia yang dilakukan akan dilihat oleh Tuhan yang menjadi pusat terakhir pertanggungjawaban (Triwuyono, 2007). Jadi CSR dalam perspektif Islam merupakan pertanggung jawaban manusia untuk segala sesuatu yang sudah Tuhan berikan untuknya agar manusia dalam keadaan yang fitrah ketika kembali ke Tuhannya (Sidik dan Reskino, 2016).

Dalam SET, Tuhan dijadikan pusat untuk segala sesuatu, bukan manusia karena manusia akan kembali kepada Tuhannya. Manusia hanya perlu mengurus kekayaan alam dan beribadah kepada Tuhan selama berada di dunia. Begitu pula untuk perusahaan yang menerapkan prinsip syariah, semua kegiatan yang dilakukan di perusahaan harus sesuai dengan hukum syariah karena setiap kegiatannya merupakan tanggung jawabnya. Jadi SET ini digunakan sebagai basis utama peneliti yang menjelaskan mengenai ICSR yang akan menjadi penentu untuk setiap kegiatan yang dilakukan perusahaan terhadap sosial dan lingkungannya agar sesuai dengan prinsip syariah yang dibuat dalam bentuk pengungkapanpengungkapan. Misalnya memberi zakat supaya bisa bermanfaat untuk masyarakat karena zakat termasuk ke dalam ICSR yang merupakan kontribusi untuk masyarakat yang membutuhkan (Sidik dan Reskino, 2016).

\section{Kinerja Perusahaan}

Kinerja merupakan hasil atau pencapaian seseorang maupun sekelompok orang dari suatu kegiatan yang telah dilaksanakan. Kinerja perusahaan adalah pencapaian perusahaan melalui kegiatan-kegiatan yang dilakukan perusahaan setiap periodenya. Menurut Kusumo (2008) dalam Meilani (2015), agar dapat mengetahui kekuatan dan kelemahan perusahaan diperlukan penilaian kinerja supaya kekuatan perusahaan bisa dipahami dan diambil manfaatnya dan dapat memperbaiki kelemahannya dengan beberapa langkah yang dapat dilakukan untuk menyelesaikannya. Pada bank syariah, penilaian kinerja ini akan menentukan apakah dalam laporan tahunannya baik berupa laporan keuangan maupun non keuangan sesuai dengan prinsip syariah. Hal ini dilakukan agar masyarakat dapat memberikan respon positif terhadap bank syariah. Menurut Sidik dan Reskino (2016), indeks komposit kesehatan bank dapat digunakan untuk mengukur kinerja dalam dunia perbankan.

Dalam penelitian ini, yang digunakan untuk mengukur kinerja bank umum syariah berdasarkan pada aturan OJK Nomor 8/POJK.03/2014 adalah rasio profitabilitas yang terdiri dari ROA, ROE, dan NIM. ROA digunakan untuk meggambarkan kemampuan manajemen bank dalam menghasilkan laba dari penggunaan aset. ROE digunakan untuk menggambarkan kemampuan bank dalam menghasilkan laba setelah pajak dari pengelolaan modal. NIM digunakan untuk menggambarkan kemampuan manajemen bank dalam mengelola aktiva produktif untuk menghasilkan pendapatan bunga bersih, untuk bank syariah disebut sebagai pendapatan bagi hasil.

Berikutnya yang dijadikan pengukuran kinerja bank umum syariah adalah rasio kecukupan modal. Rasio yang akan digunakan adalah CAR (Capital Adequacy Ratio), karena 
CAR menggambarkan kemampuan bank dalam meyediakan dana yang digunakan untuk menghadapi terjadinya kerugian.

\section{Islamic Islamic Corporate Social Responsibility (ICSR)}

ICSR merupakan perkembangan dari CSR konvensional sehingga menjadi CSR Islami. Zakat, sedekah, memberi makan orang miskin, berinfak, memberikan pinjaman kepada masyarakat yang sedang membutuhkan merupakan bagian dari konsep amal yang terdapat dalam ajaran Islam (Sidik dan Reskino, 2016). ICSR adalah tanggung jawab sosial yang memiliki nilai-nilai Islami yang terdapat di dalam Al-Qur'an dan hadist (Khursid et al., 2014). Sehingga bank syariah, dalam praktik pelaporan sosial mereka diharapkan dapat memberikan gambaran tingkat CSR perusahaan yang tinggi dan jelas dari laporan tahunan (Zubairu et al. 2011).

Perusahaan melakukan pelaksanaan CSR yang akan disosialisasikan pada publik yang salah satunya terdapat di dalam pengungkapan sosial pada laporan tahunan (annual report). Laporan tahunan yang dibuat perusahaan akan mencerminkan kinerjanya secara komprehensif kepada para pemegang saham, calon investor, pemerintah maupun masyarakat. Tujuan dari laporan tahunan ini yaitu untuk menentukan dan menjelaskan dalam bentuk laporan kegiatan perusahaan terhadap lingkungan sosial (Belkaoui, 2007).

Kajian teori tentang ICSR pertama kali dikembangkan oleh penelitian Haniffa (2002) agar dapat membantu perusahaan dalam membuat laporan pengungkapan dengan melakukan pengembangan konsep pengungkapan CSR untuk perusahaan Islam. Hasilnya penelitian tersebut menjadi Islamic Social Reporting Disclosure (ISR) yang sesuai dengan prinsip ketauhidan, hukum syariah dan etika. Terdapat 5 unsur tema dari pengungkapan ISR yang terdiri dari keuangan dan investasi, produk, karyawan, masyarakat, dan lingkungan.

Kemudian penelitian pengungkapan ISR dikembangkan lagi oleh Othman et, al. (2009) dari penelitian sebelumnya yang dilakukan oleh Haniffa (2002). Ada satu tema oleh Othman yaitu tata kelola sehingga tema menjadi 6 unsur yang terdiri dari keuangan dan investasi, produk dan jasa, karyawan, masyarakat, lingkungan dan tata kelola.

\section{Sharia Governance}

Sharia Governance yang terdapat di dalam IFSB (IFSB-10, 2009) adalah kumpulan peraturan untuk lembaga keuangan syariah untuk mengetahui adanya pandangan independen mengenai kepatuhan syariah dalam melakukan proses penerbitan, penyebaran informasi, dan review internal. Di bank syariah, Sharia Governance yaitu penggabungan dari konsep Good Corporate Governance dan Sharia Compliance (Wardayati, 2011). Bank Indonesia menyatakan bahwa GCG bank harus menerapkan prinsip-prinsip transparansi, akuntabilitas, pertanggungjawaban, profesional, dan kewajaran. Berikutnya dari bagian Sharia Governance yaitu Shariah compliance dimana bank syariah harus mematuhi prinsip syariah karena merupakan kewajibannya. Implementasi GCG dalam perbankan syariah, supaya dapat memastikan bahwa bank syariah memenuhi prinsip syariah, maka diwajibkan untuk melakukan penerapan shariah compliance.

Konsep sharia governance yang telah dikeluarkan oleh IFSB bagi bank syariah, memandang dari sistem tata kelola sebagai komplementer. Sebagai elemen utama dari sistem tata kelola perusahaan, selain dewan direksi, audit internal dan eksternal, dan unit kepatuhan, bank syariah harus mempunyai Dewan Pengawas Syariah karena dalam sistem sharia governance, DPS memiliki peran penting untuk kepatuhan syariah dalam proses supervisi, monitoring, audit dan pemberian opini. DPS merupakan badan yang memiliki wewenang memberi nasehat dan mengawasi serta melihat aktivitas yang dilakukan pada lembaga keuangan syariah supaya dapat mengikuti dan mentaati aturan berdasarkan prinsip-prinsip syariah (Rama, 2014). 


\section{Hubungan Islamic Islamic Corporate Social Responsibility (ICSR) terhadap kinerja perusahaan}

Meningkatkan maupun mempertahankan kinerja merupakan suatu tuntutan untuk perusahaan agar jika terjadi krisis perusahaan dapat mempertahankannya. Itupun berlaku juga untuk perusahaan dengan semakin ketatnya persaingan perusahaan (Arifin dan Wardani, 2016). Perusahaan harus memiliki reputasi yang baik dengan meningkatkan kinerjanya karena itu merupakan modal perusahaan. Untuk mendapatkan akses sumber daya dan kinerja secara luas, maka dukungan stakeholder diperlukan untuk mencapai keberhasilan perusahaan dalam melakukan kegiatan filantropi yang Islami (Sidik dan Reskino, 2016).

Untuk mendapatkan kepercayan dari masyarakat, tidak hanya pengungkapan laporan keuangan, melainkan pengungkapan tanggung jawab sosial (ICSR). ICSR ini akan menentukan kinerja perusahsaan apakah sesuai berdasarkan prinsip-prinsip syariah. Hal ini akan terlihat dari perusahaan yang memberikan pengungkapan kepada masyarakat. Perusahaan dengan ICSR yang baik, mendapatkan respon yang baik dari investor dari peningkatan fluktuasi harga saham perusahaan. Sebaliknya, perusahaan dengan ICSR yang buruk, kana mendapatkan respon yang buruk dari investor karena menurunnya fluktuasi harga saham (Almilia dan Wijayanto, 2007).

Dapat diketahui dari penjelasan tersebut, bahwa hubungan ICSR dan kinerja perusahaan terlihat dari bagaimana perusahaan dalam memberikan pengungkapan kepada masyarakat agar masyarakat dapat menilai kinerja perusahaan. Pengungkapan yang semakin baik, maka kinerjanya juga akan semakin membaik, begitu pun sebaliknya. Penelitian Arifin dan Wardani (2016) yang sudah dilakukan sebelumnya, menggunakan dua proksi untuk pengukuran kinerjanya yaitu ROE dan ROA. Hasil penelitiannya menunjukkan bahwa ICSR memiliki pengaruh signifikan terhadap kinerja perusahaan yang pengukurannya menggunakan ROE, tetapi tidak mempunyai pengaruh terhadap ROA. Kemudian penelitian Sidik dan Reskino (2016) menunjukkan ICSR hanya berpengaruh positif tetapi tidak berpengaruh terhadap kinerja perusahaan (ROE). Penelitian Indrayani dan Risna (2018) juga menunjukkan bahwa ICSR tidak mempunyai pengaruh terhadap kinerja perusahaan (ROA). Untuk penelitian ini akan ditambahkan rasio NIM dan CAR sebagai pengukuran kinerja. Berdasarkan teori dan hasil penelitian yang telah dikemukakan sebelumnya, maka dapat diasumsikan terdapat hubungan positif antara ICSR terhadap kinerja perusahaan.

\section{Hubungan Sharia Governance terhadap kinerja perusahaan}

Untuk bank syariah harus memiliki Dewan Pengawas Syariah (DPS) dalam melalukan kegiatan yang berdasarkan prinsip syariah karena DPS merupakan elemen penting untuk ssitem sharia governance. DPS ialah badan independen yang setiap kegiatannya bertugas melakukan pengarahan, memberi konsultasi, evaluasi, dan pengawasan agar kegiatan di bank syariah dapat dipastikan sesuai dengan prinsip syariah (Fauzi, 2016).

Sharia Governance akan dilihat dari jumlah Rapat Dewan Pengawas Syariah (DPS). Peraturan BI Nomor 11/33/PBI tahun 2009 di pasal 49 menjelaskan GCG yang dilakukan baik di Bank Umum Syariah maupun Unit Usaha Syariah, rapat DPS wajib dilakukan setidaknya sekali dalam sebulan, dan keputusan diambil secara musyawarah mufakat. Jika sering melakukan rapat DPS, maka kinerja perusahaan akan semakin meningkat karena operasional perusahaan tetap berjalan berdasarkan prinsip syariah (Fauzi, 2016).

Dari penjelasan di atas, hubungan Sharia Governanance dan kinerja perusahahaan akan dilihat dari berapa banyak bank syariah melakukan rapat Dewan Pengawas Syariah. Rapat ini wajib dilakukan untuk Bank Umum Syariah minimal satu kali dalam sebulan. Jika rapat DPS sering dilakukan maka kinerjanya akan semakin baik supaya dalam rapat tersebut, dapat mengambil keputusan secara musyawarah mufakat. 
Penelitian tentang Sharia Governance terhadap kinerja sudah dilakukan Sunarwan (2016), hasilnya menunjukkan bahwa Corporate Governance yang diukur dengan rapat DPS mempunyai pengaruh yang signifikan terhadap kinerja pada bank syariah. Penelitian ini memiliki perbedaan penelitian dengan Kartika (2014), Fauzi (2016), dan Eksandy (2018) dimana hasil penelitiannya menunjukkan bahwa tidak ada pengaruh antara Dewan Pengawas Syariah dan kinerja perbankan. Indrayani dan Risna (2018) juga menunjukkan hasil penelitiannya bahwa Sharia Governance tidak memiliki pengaruh terhadap kinerja (ROA). Dari teori dan hasil penelitian yang dikemukakan di atas, dapat diasumsikan bahwa Sharia Governance dalam hal rapat Dewan Pengawas Syariah memiliki hubungan positif dengan kinerja perusahaan.

\section{Hipotesis}

Berdasarkan teori yang telah dijelaskan sebelumnya, maka hipotesis yang akan digunakan sebagai jawaban sementara dalam penelitian ini adalah:

H1: ICSR memiliki pengaruh positif dan signifikan terhadap kinerja (ROA)

H2: Sharia Governance memiliki pengaruh positif dan signifikan terhadap kinerja (ROA)

H3: ICSR memiliki pengaruh positif dan signifikan terhadap kinerja (ROE)

H4: Sharia Governance memiliki pengaruh positif dan signifikan terhadap kinerja (ROE)

H5: ICSR memiliki pengaruh positif dan signifikan terhadap kinerja (NIM)

H6: Sharia Governance memiliki pengaruh positif dan signifikan terhadap kinerja (NIM)

H7: ICSR memiliki pengaruh positif dan signifikan terhadap kinerja (CAR)

H8: Sharia Governance memiliki pengaruh positif dan signifikan terhadap kinerja (CAR)

\section{METODE PENELITIAN}

\section{Sampel dan Jenis Data}

Penelitian ini merupakan penelitian kuantitatif. Populasi dalam penelitian ini adalah seluruh bank umum syariah yang terdaftar di Otoritas Jasa Keuangan (OJK) dengan data time series atau cross section dari periode 2015-2019. Kriteria dalam penelitian ini adalah (1) Bank Umum Syariah yang terdaftar di Otoritas Jasa Keuangan (OJK) tahun 2015-2019; (2) Bank Umum Syariah yang melaporkan laporan tahunan secara berturut-turut dari tahun 20152019; (3) Bank Umum Syariah yang memiliki informasi terkait variabel independen dan variabel dependen dalam penelitian ini.

Setelah melakukan pengambilan sampel dengan menggunakan purposive sampling, terdapat 8 Bank Umum Syariah yang memenuhi kriteria sampel sehingga jumlah sampel yang didapatkan sebanyak 40 sampel.

\section{Variabel Penelitian dan Pengukuran}

Variabel dependen yang digunakan dalam penelitian ini adalah kinerja bank umum syariah. Berikut adalah pengukuran yang digunakan, yaitu sebagai berikut:

1. Return On Asset (ROA)

$$
\text { ROA }=\frac{\text { Laba bersih setelah pajak }}{\text { Total aktiva }} \times 100 \%
$$

\section{Return On Equity (ROE)}

$$
\mathrm{ROE}=\frac{\text { Laba Bersih Setelah Pajak }}{\text { Ekuitas }} \times 100 \%
$$


3. Net Interest Margin (NIM)

$$
\mathrm{NIM}=\frac{\text { Pendapatan Bunga Bersih }}{\text { Rata }- \text { Rata Aktiva Produktif }} \times 100 \%
$$

\section{Capital Adequacy Ratio (CAR)}

$$
\mathrm{CAR}=\frac{\text { Modal Bank }}{\text { Aktiva Tertimbang Menurut Risiko }} \times 100 \%
$$

Variabel independen pertama yang digunakan adalah Islamic Corporate Social Responsibility. Pengukuran yang digunakan untuk variabel ICSR adalah indeks Islamic Social Responsibility (ISR) yang dikembangkan oleh Haniffa (2002) dan Othman (2009). ISR terdiri dari 6 tema yaitu keuangan dan investasi (Finance and Investment), produk dan jasa (Product amd Service), karyawan (Employess), masyarakat (Community Involvement), lingkungan Hidup (Environment), dan tata kelola perusahaan (Corporate Governance). Dari enam tema tersebut dikembangkan 42 sub-item. Setelah itu, melakukan skoring dengan memberikan skor pada setiap item yang diungkapkan pada laporan keuangan tahunan bank umum syariah. Skor "1" untuk sub-item yang diungkapkan dan skor "0" untuk sub-item yang tidak diungkapkan. Berikut rumus yang digunakan, yaitu sebagai berikut:

$$
\mathrm{ICSR}=\frac{\text { Item yang diungkapkan }}{\text { Jumlah total item pengungkapan }} \times 100 \%
$$

Variabel independen kedua adalah Sharia Governance. Pengukuran yamg digunakan adalah jumlah rapat Dewan Pengawas Syariah yang dilakukan setiap tahuannya.

\section{HASIL DAN PEMBAHASAN \\ Statistik Deskriptif}

Berdasarkan hasil dari analisis deskriptif, variabel independen ICSR menunjukkan nilai rata-rata (mean) sebesar 0,6511 dengan standar deviasi sebesar 0,0704. Nilai minimumnya sebesar $50 \%$ dan nilai maksimumnya sebesar $76,19 \%$. Variabel independen Sharia Governance menunjukkan nilai rata-rata sebesar 14 dengan standar deviasi 5,064. Nilai minimumnya sebesar 7 dan nilai maksimumnya sebesar 36.

Variabdel dependen ROA menunjukkan hasil rata-rata sebesar 0,0098 dengan standar deviasi sebesar 0,0087 . Nilai minimumnya adalah $-1,12 \%$ dan nilai maksimumnya adalah 2,83\%. Variabel dependen ROE menunjukkan nilai rata-rata sebesar 0,0708 dengan standar deviasi 0,7791 . Nilai minimumnya sebesar $-13,74 \%$ dan nilai maksimumnya sebesar $24,24 \%$. Variabel dependen NIM menunjukkan nilai rata-rata sebesar 0,0556 dengan standar deviasi 0,0201 . Nilai minimumnya sebesar $0,83 \%$ dan nilai maksimumnya sebesar $9,34 \%$. Variabel dependen CAR menunjukkan hasil rata-rata sebesar 0,175 dengan standar deviasi 0,0644. Nilai minimumnya sebesar $12 \%$ dan nilai maksimumnya sebesar $38,30 \%$.

\section{Uji Asumsi Klasik}

Dalam penelitian ini, untuk uji asumsi klasik terdiri dari uji normalitas, uji multikolinearitas, uji autokorelasi, dan uji heteroskedastisitas. Pada uji normalitas, dengan Kolmogorov-Smirnov mendapatkan hasil signifikansi Asiymp.Sig (2-tailed) untuk ROA 0,200, ROE 0,009, NIM 0,200 dan CAR 0,003. Pada uji normalitas ROA dan NIM menunjukkan 
hasil berdistribusi normal, sedangkan untuk ROE dan CAR menunjukkan hasil tidak berdistribusi normal karena kurang dari 0,05. Oleh karena itu, diperlukan cara untuk mengatasinya yaitu dengan cara menggunakan Monte Carlo. Setelah dilakukan Monte Carlo menunjukkan nilai Monte Carlo.Sig (2-tailed) untuk ROE sebesar 0,219 dan CAR sebesar 0,143. Ini menunjukkan bahwa data sudah berdistribusi normal.

Pada uji multikolinearitas, menunjukkan nilai tollerance sebesar $0,968(0,968 \geq 0,10)$ dan nilai VIF sebesar $1,033(1,033 \leq 10)$. Hasil ini menunjukkan bahwa tidak terjadi multikolinearitas. Pada uji autokorelasi menggunakan uji Durbin-Watson. Untuk uji autokorelasi pada ROA menunjukkan hasil sebesar 0,895, ROE sebesar 0,826, NIM sebesar 0,696 dan CAR sebesar 1,002. Untuk mengetahui apakah terjadi autokorelasi atau tidak dalam pengambilan keputusan adalah dengan membandingkan dengan tabel Durbin-Watson. Pada penelitian ini menggunakan 40 sampel $(\mathrm{N})$ dan menggunakan 2 variabel independen $(\mathrm{K})$, sehingga mendapatkan nilai dari tabel Durbin-Watson dan hasilnya adalah sebagai berikut:

$\mathrm{dl}=1,3908$

$\mathrm{du}=1,6000$

$4-\mathrm{dl}=4-1,3908=2,6092$

$4-\mathrm{du}=4-1,6000=2,4000$

Setelah melihat hasil tersebut, semua hasil uji autokorelasi baik ROA, ROE, NIM, dan CAR menunjukkan hasil terjadinya autokorelasi karena syarat uji autokorelasi adalah tidak terjadi autokorelasi $(\mathrm{du}<\mathrm{d}<4-\mathrm{du})$. Oleh karena itu untuk mengatasinya, yaitu dengan menggunakan metode Cochrane Orcutt. Setelah melalukan Cpchrane Orcutt, hasil uji untuk ROA sebesar 2,095, ROE sebesar 2,232, NIM sebesar 1,900, dan CAR sebesar 1,831. Hasil ini menunjukkan bahwa tidak terjadi autokorelasi.

Pada uji heteroskedastisitas menggunakan uji Glejser. Pada variabel ROA, nilai sig ICSR adalah 0,044 (sig < 0,05) dan nilai sig Sharia Governance sebesar 0,271 (sig > 0,05). Ini artinya bahwa terjadi heteroskedastisitas pada variabel ICSR dan tidak terjadi heteroskedastisitas pada variabel Sharia Governance. Pada variabel ROE, nilai sig ICSR adalah 0,036 (sig < 0,05) dan nilai Sharia Governance sebesar 0,455 (sig > 0,05). Hal ini menunjukkan bahwa terjadi heterokedastisitas pada variabel ICSR dan tidak terjadi heteroskedastisitas pada variabel Sharia Governance. Pada variabel NIM, nilai sig ICSR adalah 0,990 (sig > 0,05) dan nilai sig Sharia Governance sebesar 0,140 (sig > 0,05). Hal ini menunjukkan bahwa tidak terjadi heteroskedastisitas pada data penelitian. Pada variabel CAR, nilai sig ICSR adalah 0,679 (sig > 0,05) dan Sharia Governance sebesar 0,638 ( $\operatorname{sig}>0,05)$. Hal ini menunjukkan bahwa tidak terjadi heteroskedastisitas pada data penelitian.

Untuk mengatasi terjadinya heteroskedastisitas, yaitu dengan transformasi logaritma natural (LN). Pada variabel ROA, nilai sig ICSR sebesar 0,460 (sig > 0,05) dan nilai sig Sharia Governance sebesar 0,270 (sig > 0,05). Pada variabel ROE, nilai sig ICSR sebesar 0,991 (sig > 0,05) dan nilai sig Sharia Governance sebesar 0,255 (sig > 0,05). Hal ini menunjukkan bahwa tidak terjadi heteroskedastisitas.

\section{Pengujian Hipotesis}

Analisis Regresi Linear Berganda

Pengujian ini dilakukan untuk menguji apakah ICSR dan Sharia Governance berpengaruh terhadap kinerja bank umum syariah yang diukur dengan ROA, ROE, NIM, dan CAR. Berdasarkan hasil uji regresi berganda, maka dapat dianalisis model persamaan regresi linear berganda dengan 4 model persamaan, sebagai berikut:

$$
\begin{aligned}
& \mathrm{Y} 1=-0,005+0,005 \mathrm{X} 1+0,001 \mathrm{X} 2(\text { Model 1) } \\
& \mathrm{Y} 2=-0,139+0,140 \mathrm{X} 1+0,007 \mathrm{X} 2 \quad(\text { Model 2) } \\
& \mathrm{Y} 3=0,014+0,094 \times 1-0,002 \times 2 \quad \text { (Model 3) }
\end{aligned}
$$


$\mathrm{Y} 4=0,274-0,126 \mathrm{X} 1-0,002 \mathrm{X} 2 \quad($ Model 4)

Keterangan :

$\mathrm{Y} 1=$ Return On Assets $(\mathrm{ROA})$

$\mathrm{X} 1=\mathrm{ICSR}$

$\mathrm{Y} 2=$ Return On Equity (ROE)

$\mathrm{X} 2=$ Sharia Governance

$\mathrm{Y} 3=$ Net Interest Margin (NIM)

$\mathrm{Y} 4=$ Capital Adequacy Ratio (CAR)

\section{Uji Statistik F dan Koefisien Determinasi}

Uji statistik F ROA menunjukkan nilai $F_{\text {hitung }}<F_{\text {tabel }}(1,455<3,25)$ dan signifikansi sebesar $0,246(0,246>0,05)$. Hal ini menunjukkan bahwa pada uji $\mathrm{F}$ tidak menunjukkan hasil yang signifikan. Oleh karena itu, pada penelitian ini akan melakukan outlier atau membuang data yang dianggap memiliki nilai ekstrim dengan casewise diagnitics. Setelah melakukan outlier, terdapat 6 sampel dari 40 sampel yang dianggap memiliki nilai ekstrim sehingga total sampel yang digunakan adalah 34 sampel. Setelah outlier, uji F variabel ROA menunjukkan hasil $F_{\text {hitung }}>F_{\text {tabel }}(6,844>3,30)$ dan signifikansi $0,003(0,003<0,05)$. Jadi hasil ini menunjukkan bahwa ICSR dan Sharia Governance secara bersama-sama berpengaruh signifikan terhadap ROA. Berikutnya pada koefisien determinasi ROA menunjukkan hasil Adjusted $R$ Square sebesar 0,262 atau 26,2\%. Hal ini menunjukkan bahwa kontribusi ICSR dan Sharia Governance dalam menjelaskan variabel ROA adalah sebesar 26,2\% dan sisanya $73,8 \%$ dijelaskan oleh variabel lain diluar variabel yang diuji.

Uji $\mathrm{F}$ ROE menunjukkan nilai hasil $\mathrm{F}_{\text {hitung }}<\mathrm{F}_{\text {tabel }}(1,466<3,25)$ dan signifikansi sebesar 0,244 $(0,244>0,05)$. Hal ini menunjukkan bahwa pada uji $\mathrm{F}$ tidak menunjukkan hasil yang signifikan. Oleh karena itu, peneliti melakukan outlier atau membuang data yang dianggap memiliki nilai ekstrim dengan casewise diagnotics. Setelah melakukan outlier, terdapat 7 sampel dari 40 sampel yang dianggap memiliki nilai ekstrim sehingga total sampel yang digunakan adalah 33 sampel. Setelah outlier, uji F ROE menunjukkan hasil $\mathrm{F}_{\text {hitung }}>$ $F_{\text {tabel }}(20,360>3,32)$ dan signifikansi $0,000(0,000<0,05)$. Jadi hasil ini menunjukkan bahwa ICSR dan Sharia Governance secara bersama-sama berpengaruh signifikan terhadap ROE. Berikutnya pada koefisien determinasi ROE menunjukkan hasil Adjusted $R$ Square sebesar 0,548 atau 54,8\%. Hal ini menunjukkan bahwa kontribusi ICSR dan Sharia Governance dalam menjelaskan variabel ROE adalah sebesar 54,8\% dan sisanya 45,2\% dijelaskan oleh variabel lain diluar variabel yang diuji.

Uji $\mathrm{F}$ NIM menunjukkan nilai hasil $\mathrm{F}_{\text {hitung }}<\mathrm{F}_{\text {tabel }}(0,809<3,25)$ dan signifikansi sebesar $0,453(0,453>0,05)$. Hal ini menunjukkan bahwa pada uji $\mathrm{F}$ tidak menunjukkan hasil yang signifikan. Oleh karena itu, peneliti harus melakukan outlier atau membuang data yang dianggap memiliki nilai ekstrim. Setelah melakukan outlier, terdapat 5 sampel dari 40 sampel yang dianggap memiliki nilai ekstrim sehingga total sampel yang digunakan adalah 35 sampel. Setelah outlier, uji F NIM menunjukkan hasil $F_{\text {hitung }}>F_{\text {tabel }}(8,542>3,29)$ dan signifikansi 0,001 $(0,001<0,05)$. Jadi hasil ini menunjukkan bahwa ICSR dan Sharia Governance secara bersama-sama berpengaruh signifikan terhadap NIM. Berikutnya pada koefisien determinasi NIM menunjukkan hasil Adjusted $\mathrm{R}^{2}$ sebesar 0,307 atau 30,7\%. Hal ini menunjukkan bahwa kontribusi ICSR dan Sharia Governance dalam menjelaskan variabel NIM adalah sebesar 30,7\% dan sisanya $69,3 \%$ dijelaskan oleh variabel lain diluar variabel yang diuji.

Uji F CAR menunjukkan nilai hasil $\mathrm{F}_{\text {hitung }}<\mathrm{F}_{\text {tabel }}(1,239<3,25)$ dan signifikansi sebesar 0,302 $(0,302>0,05)$. Hal ini menunjukkan bahwa pada uji $\mathrm{F}$ tidak menunjukkan hasil yang signifikan. Oleh karena itu, peneliti harus melakukan outlier atau membuang data yang dianggap memiliki nilai ekstrim. Setelah melakukan outlier, terdapat 8 sampel dari 40 sampel yang dianggap memiliki nilai ekstrim sehingga total sampel yang digunakan adalah 32 
sampel. Setelah outlier, uji $F$ CAR menunjukkan hasil $F_{\text {hitung }}>F_{\text {tabel }}(4,479>3,33)$ dan signifikansi $0,020(0,020<0,05)$. Jadi hasil ini menunjukkan bahwa ICSR dan Sharia Governance secara bersama-sama berpengaruh signifikan terhadap CAR. Berikutnya pada koefisien determinasi CAR menunjukkan hasil Adjusted $\mathrm{R}^{2}$ sebesar 0,183 atau 18,3\%. Hal ini menunjukkan bahwa kontribusi ICSR dan Sharia Governance dalam menjelaskan variabel CAR adalah sebesar $18,3 \%$ dan sisanya $81,7 \%$ dijelaskan oleh variabel lain diluar variabel yang diuji.

\section{Uji Statistik t dan Pembahasan}

Pada hipotesis pertama, menunjukkan nilai koefisien $(\beta 1)$ variabel ICSR sebesar 0,005 yang artinya arahnya positif dengan signifikansi sebesar $0,718>0,05$ dan nilai $t_{\text {hitung }}<$ $t_{\text {tabel }}$ yaitu $0,364<2,03951$ sehingga $\mathrm{H} 0$ diterima. Hasil ini menunjukkan bahwa ICSR tidak memiliki pengaruh signifikan terhadap ROA sehingga hasilnya adalah H1 ditolak karena tidak membuktikan bahwa ICSR memiliki pengaruh positif dan signifikan terhadap ROA. Hal ini disebabkan karena informasi yang diungkapkan dari bank umum syariah dalam Islamic Corporate Social Responsibility tidak banyak dikaitkan dengan kegiatan untuk memperoleh laba yang berasal dari penggunaan aset. Untuk mendapatkan manfaat dari CSR sehingga perusahaan dapat menciptakan value membutuhkan waktu yang relatif panjang. Misalnya, memberikan bantuan kesehatan untuk masyarakat yang kurang mampu, perusahaan tidak memperoleh keuntungan secara langsung dalam waktu yang singkat. Kemudian, banyaknya kegiatan CSR yang dilakukan oleh perusahaan dapat menyebabkan banyaknya biaya yang harus dikeluarkan perusahaan sehingga terjadinya beban keuangan. Hasil penelitian ini mendukung penelitian sebelumnya yaitu penelitian Arifin dan Wardani (2016) dan Indrayani dan Risna (2018) yang menunjukkan bahwa ICSR tidak memiliki pengaruh signifikan terhadap ROA.

Pada hipotesis kedua, menunjukkan nilai $(\beta 2)$ variabel Sharia Governance sebesar 0,001 yang artinya arahnya positif dengan signifikansi sebesar $0,001<0,05$ dan nilai $t_{\text {hitung }}>$ $t_{\text {tabel }}$ yaitu 3,662 > 2,03951 sehingga H0 ditolak. Hasil ini menunjukkan bahwa Sharia Governance memiliki pengaruh positif dan signifikan terhadap ROA sehingga hasilnya adalah $\mathbf{H 2}$ diterima. Artinya, semakin meningkat jumlah rapat Dewan Pengawas maka semakin baik pula kinerja bank umum syariah dalam menghasilkan laba dari penggunaan aset. Hasil penelitian ini sesuai dengan penelitian sebelumnya yaitu penelitian Sunarwan 2015) yang menunjukkan bahwa rapat Dewan Pengawas Syariah berpengaruh signifikan terhadap kinerja perbankan syariah yang diukur dengan ROA. Tetapi ada juga yang berbeda pada penelitian sebelumnya yaitu penelitian Indrayani dan Risna (2018) yang menjelaskan bahwa Sharia Governance dalam hal rapat Dewan Pengawas Syariah berpengaruh negatif dan signifikan terhadap kinerja bank umum syariah yang diukur dengan ROA. Begitu pula dengan penelitian Fauzi (2016) yang menjelaskan bahwa ukuran Dewan Pengawas Syariah berpengaruh negatif terhadap kinerja (ROA).

Pada hipotesis ketiga, menunjukkan nilai $(\beta 3)$ variabel ICSR sebesar 0,140 yang artinya arahnya positif dengan signifikansi sebesar $0,104>0,05$ dan nilai $t_{\text {hitung }}<\mathrm{t}_{\text {tabel }}$ yaitu $1,679<2,04227$ sehingga H0 diterima. Hasil ini menunjukkan bahwa ICSR tidak memiliki pengaruh signifikan terhadap ROE sehingga hasilnya adalah H3 ditolak karena tidak membuktikan bahwa ICSR memiliki pengaruh positif dan signifikan terhadap ROE. Hal ini disebabkan kurang panjangnya periode penelitian karena penelitian ini menggungakan jangka waktu 5 tahun. Sedangkan untuk mendapatkan value bagi perusahaan membutuhkan waktu yang lama atau relatif panjang agar dapat mengetahui peningkatan kinerja perusahaan. Jadi, karena penelitian ini menggunakan jangka waktu 5 tahun bisa dijadikan sebagai salah satu penyebab ICSR tidak signifikan terhadap kinerja yang diukur dengan ROE. Hasil penelitian ini sesuai dengan penelitian sebelumnya yaitu penelitian Sidik dan Reskino (2016) yang 
menjelaskan bahwa ICSR tidak berpengaruh signifikan terhadap ROE. Tetapi ada juga yang berbeda dengan penelitian sebelumnya yaitu penelitian Arifin dan Wardani (2016) yang menjelaskan bahwa ICSR memiliki pengaruh positif dan signifikan terhadap ROE.

Pada hipotesis keempat, menunjukkan nilai $(\beta 4)$ variabel Sharia Governance sebesar 0,007 yang artinya arahnya positif dengan signifikansi sebesar $0,000<0,05$ dan nilai $t_{\text {hitung }}>$

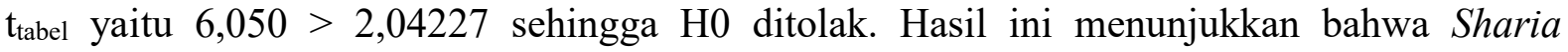
Governance memiliki pengaruh positif dan signifikan terhadap ROE sehingga hasilnya adalah $\mathbf{H} 4$ diterima. Artinya, semakin sering dilakukannya rapat Dewan Pengawas Syariah maka semakin baik pula kinerja bank umum syariah dalam mendapatkan laba setelah pajak dari pengelolaan modal. Untuk saat ini, pada hasil penelitian ini belum peneliti temukan pada penelitian sebelumnya.

Pada hipotesis kelima menunjukkan nilai ( $\beta 5)$ variabel ICSR sebesar 0,094 yang artinya arahnya positif dengan signifikansi sebesar $0,013<0,05$ dan nilai $t_{\text {hitung }}>t_{\text {tabel }}$ yaitu 2,628 > 2,03693 sehingga H0 ditolak. Hasil ini menunjukkan bahwa ICSR memiliki pengaruh positif dan signifikan terhadap NIM sehingga hasilnya adalah $\mathbf{H 5}$ diterima. Artinya setiap peningkatan pengungkapan ICSR pada bank umum syariah akan mempengaruhi peningkatan pendapatan bagi hasil dari pengelolaan aktiva produktif. Untuk saat ini, hasil penelitian ini belum peneliti temukan pada penelitian sebelumnya.

Pada hipotesis keenam, menunjukkan hasil $(\beta 6)$ variabel Sharia Governance sebesar 0,002 yang artinya arahnya negatif dengan signifikansi sebesar $0,002<0,05$ dan nilai $t_{\text {hitung }}<$ $-t_{\text {tabel }}$ yaitu $-3,451<-2,03693$ sehingga H0 ditolak. Hasil ini menunjukkan bahwa Sharia Governance memiliki pengaruh negatif dan signifikan terhadap NIM sehingga hasilnya adalah H6 ditolak karena tidak membuktikan bahwa Sharia Governance memiliki pengaruh positif dan signifikan terhadap NIM. Pengaruh negatif ini disebabkan karena ada beberapa bank umum syariah dalam menjalankan rapat Dewan Pengawas Syariah belum menjalankan sesuai dengan aturan dimana rapat dilakukan setidaknya minimal sekali sebulan atau 12 kali dalam setahun. Misalnya, pada Bank Acek Syariah tahun 2015 dan 2016 hanya menjalankan rapat sebanyak 7 kali dalam setahun, pada Bank Syariah Mandiri tahun 2017 dan 2018 hanya menjalankan rapat sebanyak 9 kali dalam setahun. Untuk hasil penelitian ini belum peneliti temukan pada penelitian sebelumnya.

Pada hipotesis ketujuh menunjukkan hasil $(\beta 7)$ variabel ICSR sebesar $-0,126$ yang artinya arahnya negatif dengan signifikansi sebesar $0,076>0,05$ dan nilai $t_{\text {hitung }}>-t_{\text {tabel }}$ yaitu 1,843 > -2,04523 sehingga H0 diterima. Hasil ini menunjukkan bahwa ICSR tidak memiliki pengaruh signifikan terhadap CAR sehingga hasilnya adalah $\mathbf{H} 7$ ditolak karena tidak membuktikan bahwa ICSR memiliki pengaruh positif dan signifikan terhadap CAR. Artinya, peningkatan pengungkapan ICSR tidak berkaitan dengan kinerja perusahaan dalam menyediakan dana untuk menghadapi risiko kerugian. Hal ini bisa disebabkan karena rendahnya pengungkapan ICSR yang dilakukan oleh bank umum syariah. Misalnya pada Bank Mega Syariah tahun 2015 yang pengungkapannya hanya sebesar 50\%. Penyebab lain ICSR tidak berpengaruh terhadap kinerja yang diukur dengan CAR juga bisa disebabkan karena periode pengamatan yang rentang waktunya hanya 5 tahun. Untuk hasil penelitian ini, belum peneliti temukan pada penelitian sebelumnya.

Pada hipotesis kedelapam ( $\beta 8$ ) variabel Sharia Governance sebesar -0,002 yang artinya arahnya negatif dengan signifikansi sebesar $0,048<0,05$ dan nilai $\mathrm{t}_{\text {hitung }}<-\mathrm{t}_{\text {tabel }}$ yaitu $2,064<2,04523$ sehingga H0 diterima. Hasil ini menunjukkan bahwa Sharia Governance memiliki pengaruh negatif dan signifikan terhadap CAR sehingga hasilnya adalah H8 ditolak karena tidak membuktikan bahwa Sharia Governance memiliki pengaruh positif dan signifikan terhadap CAR. Artinya, semakin sering rapat Dewan Pengawas Syariah yang dilakukan oleh bank umum syariah akan membuat kinerja perusahaan dalam menyediakan dana untuk menghadapi risiko kerugian semakin menurun. Penyebab pengaruh negatif 
disebabkan karena ada beberapa bank umum syariah dalam menjalankan rapat Dewan Pengawas Syariah belum menjalankan sesuai dengan aturan dimana rapat dilakukan setidaknya minimal sekali sebulan atau 12 kali dalam setahun. Misalnya, pada Bank Acek Syariah tahun 2015 dan 2016 hanya menjalankan rapat sebanyak 7 kali dalam setahun, pada Bank Syariah Mandiri tahun 2017 dan 2018 hanya menjalankan rapat sebanyak 9 kali dalam setahun. Untuk hasil penelitian ini belum ada peneliti temukan pada penelitian sebelumnya.

\section{SIMPULAN, KETERBATASAN, DAN SARAN Simpulan}

Tujuan pada penelitian ini ialah untuk mengetahui pengaruh Islamic Corporate Social Responsibility dan Sharia Governance terhadap kinerja bank umum syariah tahun 2015-2019. Berikut kesimpulan pada penelitian ini, yaitu:

1. Islamic Corporate Social Responsibility tidak berpengaruh signifikan terhadap ROA.

2. Sharia Governance memiliki pengaruh positif dan signifikan terhadap ROA.

3. Islamic Corporate Social Responsibility tidak memiliki pengaruh signifikan terhadap ROE.

4. Sharia Governance memiliki pengaruh positif dan signifikan terhadap ROE.

5. Islamic Corporate Social Responsibility memiliki pengaruh positif dan signifikan terhadap NIM.

6. Sharia Governance memiliki pengaruh negatif dan signifikan terhadap NIM.

7. Islamic Corporate Social Responsibility tidak memiliki pengaruh signifikan terhadap CAR.

8. Sharia Governance memiliki pengaruh negatif dan signifikan terhadap CAR.

\section{Keterbatasan}

Beberapa keterbatasan dalam penelitian ini, yaitu:

1. Nilai Adjusted $R^{2}$ untuk ROA sebesar 26,2\%, ROE sebesar 54,8\%, NIM sebesar 30,7\%, dan CAR sebesar $18,3 \%$ sehingga masih banyak variabel lain yang mempengaruhi kinerja bank umum syariah.

2. Penelitian ini menggunakan 8 bank umum syariah dengan rentang waktu 5 tahun yaitu dari tahun 2015-2019 sehingga masih relatif sedikit.

3. Sumber informasi dalam penelitian ini hanya menggunakan laporan keuangan tahunan perusahaan sehingga tidak semua item pada daftar pengungkapan tanggung jawab sosial dengan menggunakan indeks ISR sebagai pengukuran ICSR diungkapkan dengan jelas.

4. Pada variabel kinerja, pengukuran yang digunakan hanya Return On Assets, Return On Equity, Net Interest Margin, dan Capital Adequacy Ratio.

\section{Saran}

Saran bagi penelitian berikutnya yaitu:

1. Untuk peneliti berikutnya bisa menambahkan variabel-variabel independen lain yang memiliki pengaruh terhadap kinerja bank umum syariah di Indonesia.

2. Peneliti berikutnya bisa menambahkan periode pengamatan setidaknya minimal lima tahun untuk dapat melihat perkembangan bank umum syariah di Indonesia.

\section{DAFTAR PUSTAKA}

Almilia, L. S., \& Wijayanto. (2007). Pengaruh Enviromental Performance dan Environmental Disclosure terhadap Economic Performance. The 1st Accounting Conference. UI. Depok 
Arifin, J., \& Wardani, E. A. (2016). Islamic Corporate Social Responsibility Disclosure, Reputasi, dan Kinerja Keuangan: Studi pada Bank Syariah di Indonesia. Jurnal Akuntansi dan Auditing Indonesia . Universitas Islam Indonesia

Azheri, B. (2012). Corporate Social Responsibility: Dari Voluntary menjadi Mandatory. Jakarta: Rajawali Pers.

Belkaoui, A. R. (2007). Accounting Theory. Jakarta: Salemba Empat.

Carrol, A. B. (1979). A Three-dimensional Conceptual Model of Corporate Performance. Academy of Management Review, vol. 4, hal. 497-505.

Dendawijaya, L. (2003). Manajemen Perbankan. Jakarta: Ghalia Indonesia.

Diyaul-Haq, Z. M., \& Santoso, A. L. (2016). Pengaruh Profibilitas, Penghargaan dan Tipe Kepemilikan Bank Umum Syariah Terhadap Pengungkapan Islamic Social Reporting. Simposium Nasional Akuntansi XIX. Lampung

Eksandy, A. (2018). Pengaruh Good Corporate Governance terhadap Kinerja Keuangan pada Perbankan Syariah Indonesia. Jurnal Akuntansi, Vol. 5 No. 1. Universitas Muhammadiyah. Tangerang.

Fauzi, N. A. (2016). Pengaruh Good Corporate Governance Terhadap Kinerja Keuangan (Studi pada Bank Umum Syariah Tahun 2011-2015). Tesis (S2) . Program Studi Manajemen Keuangan Perbankan Syariah. IAIN. Surakarta.

Ghozali, I. (2016). Aplikasi Analisis Multivariat dengan Program IBM SPSS 23 Cet. ke-8. Semarang: Badan Penerbit Universitas Diponegoro.

Ghozali, I. (2018). Aplikasi Analisis Multivariate dengan Program IBM SPSS 25.Semarang: Badan Penerbit Universitas Diponegoro.

Guthrie, J., \& Mathews, M. R. (1985). Corporate Social Performance in Australia. Research in Corporate Social Performance and Policy 7: 251-277.

Haniffa. (2002). Social Reporting Disclosure : An Islamic Perpective. Indonesian Management dan Accounting Research, vol. 1 no. 2, hal 128-146.

Hakkanson, N. H. (1983). Comment on Weick and Ross. The Accounting Review , vol. 58 no. 2, hal. 381-384.

IFSB (Islamic Financial Services Board). (2009). Guiding Principles on Shari'ah Governance Systems for Institutions Offering Islamic Financial Services.

Indrayani, \& Risna. (2018). Pengaruh Islamic Corporate Social Responsibility (ICSR) dan Sharia Governance terhadap Kinerja Perusahaan (Stud Empiris Bank Umum Syariah Tahun 2012-2016). Jurnal Akuntansi, Keuangan, dan Perpajakan Indonesia. Universitas Malikussaleh. Aceh.

Indriantoro, N., \& Supomo, B. (2011). Metodologi Penelitian Bisnis untuk Akuntansi dan Manajemen (ed.ke-1). Yogyakarta: BPFE.

Ismail. (2011). Perbankan Syariah. Jakarta: Prenada Media.

Khursid, M. A., Aali, A. A., Soliman, A. A., \& Amin, S. M. (2014). Developing an Islamic Corporate Social Responsibility Model. Competiveness Review, Vol.24 No.4, hal. 258-274. College of Business Administration, King Saud University, Riyadh and Development, University Technology Malaysia. Malaysia.

Marsuni, N. S. (2019). Pengaruh Praktik Islamic Corporate Social Responsibilty (ICSR) Terhadap Kinerja Keuangan Pada Bank Umum Syariah Periode 2014-2018. Skripsi. Universitas Muhammadiyah Makassar.

Meilani, S.E.R. (2016). Penerapan good governance business syariah (ggbs) dan voluntary disclosure (studi pada perusahaan perbankan syariah di Indonesia Periode 2010-2014). Jurnal EKA CIDA Vol 1 No. 1,ISSN: 2503-3565 ISSN: 2503-3689.

Othman, R., Thani, A. M., \& Ghani, E. K. (2009). Determinants of Islamic Social Reporting Among Top ShariahApproved Companies in Bursa Malaysia. Research Journal of International Studies (Issue 12). 
Otoritas Jasa Keuangan. POJK No. 8/POJK.03/2014 tentang Penilaian Tingkat Kesehatan Bank Umum Syariah Dan Unit Usaha Syariah. Diakses pada website OJK : https://www.ojk.go.id/id/kanal/syariah/regulasi/peraturan-ojk-terkaitsyariah/Pages/39peraturan-otoritas-jasa-keuangan-tentang-penilaian-tingkatkesehatan-bank-umum-syariah-dan-unit-usaha-syariah.aspx. pada 16-01-2020.

Peraturan Bank Indonesia No.11/33/PBI/2009 tentang Pelaksanaan Good Corporate Governance bagi Bank Umum Syariah dan Unit Usaha Syariah.

Raharo, S. (2017). SPSS Indonesia ; Olah Data Statistk dengan SPSS. www.spssindonesia.com. 29 Maret 2021.

Rama, A. (2014). Analisis Komparatif Model Syariah Governance Lembaga Keuangan Syariah: Studi Kasus Negara ASEAN. Laporan Penelitian Publikasi Nasional, Pusat Penelitian dan Penerbitan Lembaga Penelitian dan Pengabdian Masyarakat UIN Syarif Hidayatullah Jakarta.

Rama, A., dan Novela. (2015). Shariah Governance dan Kualitas Tata Kelola Perbankan Syariah. Jurnal Signifikan Vol. 4 No. 2, UIN Syarif Hidayatullah. Jakarta.

Rivai, V., \& Basri, A. F. (2004). Performance Aprraisal: Sistem yang Tepat untuk Menilai Kinerja Karyawan dan Meningkatkan Daya Saing Perusahaan. PT Grafindo Persada. Jakarta.

Rudianto. (2003). Akuntansi Manajemen. Jakarta: Erlangga.

Scholastic Dictionary. (2011). Scholastic Children's Dictionary ages 8 and up. Scholastic Inc. United State of America.

Sholekah, E. Nikmatush. (2018). Pengaruh Pengungkapan Islamic Corporate Social Responsibility Terhadap Kinerja Keuangan dengan Good Corporate Governance Sebagai Variabel Moderating. Skripsi.Fakultas Ekonomi Universitas Islam Negri Maulana Malik Ibrahim.

Sidik, I., \& Reskino. (2016). Pengaruh Zakat dan ICSR terhadap Reputasi dan Kinerja. Jurnal SNA vol. XIX. Lampung.

Sudana, M. I. (2011). Manajemen Keuangan Perusahaan Teori dan Praktik. Jakarta: Penerbit Erlangga.

Sugiyono. (2016). Metode Penelitian Manajemen. Yogyakarta: Alfabeta.

Sukarno, Kartika, W., \& Syaichu. (2006). Analisis Faktor-Faktor yang Mempengaruhi Kinerja Bank Umum di Indonesia. Jurnal Studi Manajemen dan Organisasi ,Vol. 3, Hal. 46. Semarang.

Sunarwan, E. (2015). Pengaruh Good Corporate Governance (GCG) Terhadap Kinerja Keuangan Perbankan Syariah (Studi Kasus pada Bank Umum Syariah dan Unit Usaha Syariah di Indonesia Periode 2010-2013). Skripsi. UIN Syarif Hidayatullah. Jakarta.

Triwuyono, I. (2007). Mengangkat "singliyan" untuk Formulasi Nilai Tambah syari'ah. Simposium Nasional Akuntansi X. Unhas.

UU No. 21 Tahun 2008 tentang Perbankan Syariah.

UU No. 25 Tahun 2007 tentang Penanaman Modal.

UU PT No. 40 Tahun 2007 pasal 74 ayat 1 tentang Perseroan Terbatas

Wardayati, S. M. (2011). Implikasi Shariah Governance Terhadap Reputasi dan Kepercayaan Bank Syariah. Jurnal Walisong, Vol. 19 No. 1.

William, G., \& Zinkin, J. (2010). Islam and CSR : A Study of the Compatibility between the Tenets of Islam and the UN Gobal Impact. Journal Business of Ethics, vol. 91 no. 4, hal. 519-533.

Zubairu, U. M., Sakariyau, O. B., \& Dauda, C. K. (2011). Social Reporting Practices of Islamic Banks in Saud Arabia. International Journal of Business and Social Science 2 (23) , 193-205. 